\title{
PENGINTEGRASIAN CHARACTER BUILDING PADA MATA KULIAH PRONUNCIATION MELALUI PROJECT-BASED LEARNING
}

\author{
Jamilah \\ Fakultas Bahasa dan Seni Universitas N egeri Yogyakarta \\ email: jamilah_fbs_uny@yahoo.com
}

\begin{abstract}
A bstrak: Penelitian ini bertujuan untuk memperbaiki proses pembelajaran mata kuliah Pronunciation dan untuk mengintegrasikan character building ke dalam mata kuliah tersebut. Project-based learning adalah model pembelajaran yang dipilih untuk mencapai kedua tujuan tersebut, dan proyek yang diambil adalah pertunjukan drama. Perbaikan pembelajaran dilakukan dengan model lesson study yang diterapkan pada kelas Pronunciation IB yang terdiri dari 20 mahasiswa. Kegiatan ini dilakukan melalui tiga tahap, yaitu tahap persiapan (plan), tahap pelaksanaan (do) dan tahap evaluasi (see). Data dikumpulkan melalui observasi, dokumentasi, diskusi, dan self assessment. Hasil penelitian menunjukkan bahwa project-based learning adalah model pembelajaran yang tepat untuk mengintegrasikan character building ke dalam mata kuliah Pronunciation. Dengan project-based learning mahasiswa dapat belajar dengan gembira, mampu menerapkan kemampuan pronunciation dalam karya nyata, yaitu bermain drama. Mahasiswa juga memahami orang lain dan bertenggang rasa, bekerja sama dalam tim, bertanggung jawab, menghargai karya orang lain, mengembangkan rasa percaya diri, bersikap kritis, dan terbuka terhadap saran dan pendapat orang lain.
\end{abstract}

Kata Kunci: character building, pronounciation, project based learning

\section{INTEGRATING CHARACTER BUILDING IN PRONUNCIATION COURSE THROUGH PROJECT-BASED LEARNING}

\begin{abstract}
A bstract: This study is aimed at improving the learning process Pronunciation course and integrating character building into the course. Project-based learning is a learning model chosen to achieve these objectives, and the project taken is drama performance. The learning improvement was achieved through lesson study carried out with a model applied to the IB Pronunciation class consisting of 20 students. These activities are carried out through three stages, namely the preparatory stage (plan), the implementation phase (do) and the evaluation phase (see). Data were collected through observation, documentation, discussions, and self-assessment. The results showed that the project-based learning was a learning model appropriate for integrating character building into the Pronunciation course. By the use of project-based learning, the students could learn joyfully and be able to apply the pronunciation ability in the real work, in a drama performance. The students also understood others, developed tolerance, worked together in teams, develiped responsibility, respected the work of others, developed self-confidence, was critical as well as open to suggestions and opinions of others.
\end{abstract}

Keyw ords: character building, pronunciation, project based learning

\section{PENDAHULUAN}

Krisis multidimensional yang dihadapi bangsa Indonesiamengharuskan bangsa ini segera berbenah diri agar tidak semakin jatuh terpuruk ke jurang kehancuran. Kepribadian dan karakter bangsa yang katanya adilu hung yang selalu digembar-gemborkan selama ini nampaknya hanyalah slogan semata. Di manakah kejururan, toleransi, sopan-santun, gotong-royong yang kitabanggakan itu sehingga kita begitu mudah terlibat korupsi, mencontek, menghujat, bahkan membunuh satu sama lain? Begitu kompleksnya permasalahan ini sehingga partisipasi semua pihak sesuai dengan perannya masing-masing harus segera dilakukan.

Salah satu upaya mengembangkan kepribadian bangsa dapat dicapai melalui pembelajaran di dalam kelas. Pembelajaran 
yang dirancang secara khusus untuk mencerdaskan bangsa sekaligus membangun karakter bangsa diharapkan mampu mengurangi krisis kepribadian tersebut. $\mathrm{Pe}$ ngembangan karakter bangsa dapat disampaikan melalui mata kuliah-mata kuliah $\mathrm{Pe}$ ngembang Kepribadian (MPK), seperti PendidikanAgama, Pendidikan Pancasila, Pendidikan Kewarganegaraan, IImu Budaya Dasar, Pendidikan Kependudukan dan Lingkungan Hidup (PKLH), dan sejenisnya. Melalui mata kuliah tersebut mahasiswa diharapkan akan mampu memahami karakter-karakter yang diharapkan masyarakat dimiliki oleh setiap warganya. Di samping mata kuliah khusus tersebut, pengembangan karakter dapat diintegrasikan pada mata kuliah bidang studi pada umumnya, dengan strategi pembelajaran yang diracang khusus, yang memungkinkan mahasiswa mengembangkan sikap-sikap yang diinginkan.

Pronunciation adalah salah satu mata kuliah dasar di Jurusan Pendidikan Bahasa Inggris yang diberikan pada semester pertama yang bertujuan untuk membekali mahasiswa dengan pengetahuan dan keterampilan pengucapan/ pelafalan bahasalnggris. Posisi mata kuliah ini sangat strategis karena dua hal. Pertama, untuk membekali mahasiswa dengan pengetahuan dan keterampilan dasar untuk berbahasa Inggris lisan. Kedua, untuk menanamkan sikap-sikap dan kepribadian yang positif dalam be lajar bahasa sehingga diharapkan akan mampu memberikan fondasi untuk bersikap dalam kehidupan akademik selanjutnya. Banyak sekali nilai sikap dan kepribadianyang dapatdikembangkan melalui perkuliahan ini, antara lain: taat asas, toleransi, kerja sama, rasa percaya diri, kritis, dan terbuka terhadap kritik orang lain.

Project-based learning adalah teknik pembelajaran yang digunakan mahasiswa dengan melakukan suatu pekerjaan, baik secara individual maupun bersama untuk mencapai suatu tujuan yang telah ditetapkan. Dengan project-based learning, mahasiswa akan belajar secara aktif menerapkan segala pengetahuan dan kemampuannya untuk mengerjakan suatu proyek, yang di dalamnya dia harus berinteraksi dengan orang lain, melaporkan hasil pekerjaan di depan publik, menerima tanggapan dari peserta lain, dan pada giliran sebagai pemirsadia juga harus kritis terhadap penampilan temannya dan menyampaikan tanggapannya secara sopan dan bijaksana. Pada proses ini mahasiswa akan menggunakan bahasa Inggris secara alamiah sehingga kemampuan pronunciation akan teramati dengan jelas yang memungkinkan tumbuhnya peer correction dan peer assessment di antara mereka. Peer assessment dan peer correction akan berjalan baik jika mahasiswamampu bersikap kritis, jujur, adil dan tidak memihak. Kebiasaan ini jika dipupuk terusmenerusakan menumbuhkan kemandirian belajar dalam kelompok, yang selanjutnya akan membentuk masyarakat akademik yang tangguh.

Secara umum, penelitian ini bertujuan untuk mengintegrasikan pembelajaran karakter dalam mata kuliah Pronunciation melalui project-based learning sehingga diharapkan mampu: (1)memperbaiki proses belajar mahasiswa untuk mencapai hasil belajar yang lebih baik; dan (2) mengembangkan sikap dan kepribadian mahasiswa yang diperlukan dalam kehidupan bermasyarakat, yaitu memiliki tanggung jawab, mampu bekerja dalam tim, bersifat kritis dan terbuka terhadap saran teman, peduli, dan menghargai orang lain.

Zuchdi (2010) mengemukakan bahwa pengintegrasian nilai-nilai moral ke dalam perkuliahan mesti disampaikan secara komprehensif. Metode komprehensif meliputi 
duametode tradisional, yaitu inkulkasi (pe nanaman) nilai dan pemberian teladan, serta dua metode kontemporer, yaitu fasilitasi nilai dan pengembangan keterampilan hidup (soft skill).

Secara tradisional, penanaman nilai dilakukan dengan cara keteladanan sehingga guru atau dosen yang ingin menanamkan nilai-nilai tertentu kepada anak didiknya harus mampu menunjukkan bahwa nilai-nilai tersebut juga ada pada dirinya, baik ketika dirinya berada di dalam kelas mengelola pembelajaran maupun berada di luar kelas. Ketika guru berada di dalam kelas mengelola pembelajaran, dia harus bersifat demokratis dan tidak otoriter sehingga dalam menentukan peraturan kelas me libatkan siswa, dalam menyampaikan pendapat, keberatan terhadap pendapat orang lain, atau memberikan sangsi terhadap pelanggaran peraturan selalu disertai dengan alasan yang rasional, memperlalukan se mua siswa dengan adil, menghargai pendapat siswa betapapun pendapat tersebut sangat naïf atau aneh, dan tetap membuka komunikasi dengan pihak-pihak yang tidak menyetujui pendapatnya. A pabila se orang guru ingin menanamkan kedisiplinan pada siswa, dia sendiri harus disiplin. Indikatornya adalah datang tepat waktu, menggunakan waktu dengan efisien, tidak pernah mengosongkan kelas tanpa alasan, menyelesaikan pekerjaan (koreksi, misalnya) tepat waktu, dan sebagainya.

Metode kontemporer, yaitu fasilitasi nilai dan pengembangan keterampilan hidup (soft skill) yang dilakukan melalui pendekatan atau teknik pembelajaran yang dipilih. Fasilitasi nilai berarti memberikan kesempatan kepada siswa untuk mengembangkan karakter atau nilai-nilai yang diinginkan. Melalui kegiatan-kegiatan yang dilakukan siswa, misalnya melakukan permainan, berdiskusi, mengerjakan kuis, ber- main peran, bermain drama, yang diharapkan membawa dampak positif terhadap perkembangan kepribadiannya. Disamping itu, kegiatan-kegiatan tersebut juga dirancang untuk membekali mereka dengan keterampilan hidup yang diperlukan, misalnya: mampu berfikir kritis, kreatif, berkomunikasi dengan jelas, mampu menyimak dengan baik, bersifat asertif, mampu meme cahkan masalah yang dihadapi, dan lainlain, yang secara ringkas keterampilan-keterampilan tersebut dinamakan keterampilan akademik dan keterampilan sosial.

Berdasarkan Kurikulum Pendidikan Bahasa Inggris (2006), Pronunciation adalah salah satu mata kuliah dasar pada Jurusan Pendidikan Bahasa Inggris yang bertujuan membekali mahasiswa dengan pengetahuan dan keterampilan pengucapan bahasa Inggris. Mata kuliah ini sangat besar sumbangannya pada kemampuan mahasiswa dalam berbahasa Inggris lisan, baik reseptif (listening) maupun produktif (speaking). Mata kuliah ini diberikan pada semester pertama sehingga menjadi sangat strategis untuk mengembangkan karakter mahasiswa agar lebih siap dalam menjalani kehidupan sosial dan akademik di lingkungan kampus.

Belajar pronunciation memiliki dua tujuan. Pertama, untuk mencapai kemampuan memproduksi bunyi bahasa mendekati kualitas native speaker (penutur asli). Kedua untuk bisa menghasilkan bahasa yang dapat dipahami dengan mudah dan benar, meskipun aksennya tidak begitu sempurna. Paulston \& Bruder (1976:82) mengatakan bahwa tujuan belajar pronunciation adalah kemampuan memproduksi bunyi bahasa kedua atau bahasa asing yang tidak menghambat jalannya komunikasi, baik dari sisi pembicara maupun pendengar. Berdasarkan pendapat tersebut, tujuan minimal belajar pronunciation adalah agar bahasa yang 
kita ucapkan dapat mudah dipahami (intelligible). Setiap orang yang belajar bahasa Inggris harus mencapai tujuan ini, sedangkan untuk mahasiswa Jurusan Pendidikan Bahasa Inggris semestinya untuk tujuan yang lebih tinggi, yaitu mampu memproduksi bahasa lisan sebagaimana para penutur asli atau mendekati penutur asli. Belajar pronunciation meliputi kemampuan memahami dan kemampuan memproduksi bahasa yang dipelajari. Menurut Kelly (2000), materi yang tercakup dalam pembelajaran Pronunciation meliputi tiga hal, yaitu: (1) segmental features of phonology (consonantsvoiced, unvoiced-vowels-long and short- and diphtongs); (2) suprasegmental features of phonology (stress, intonation); dan (3) other aspects of connected speech (assimilation, elision, linking and intrusion, junctures and contractions).

MenurutWangGe (2006), project based learning (PBL) dapat didefinisikan sebagai suatu pendekatan pengajaran yang kontekstual yang peserta didiknya dihadapkan pada suatu permasalahan atau pekerjaan sehingga mereka harus bekerja untuk memecahkan masalah tersebut atau untuk membuat produk yang harus mereka tunjukkan. Pengajaran ini tidak teacher centered, melainkan student centered yang memungkinkan peserta didik belajar secara menyeluruh dan mengintegrasikan belajar ke dalamisu kehidupan nyata. Project based learning juga dikenal dengan nama problem-based teaching, authenticlearning, atau anchored instruction yang mengikuti filosofi metode be lajar Socrates dan yang menerapkan teori pendidikan dan psikologi kognitif. Model belajar ini juga berdasarkan pada purposeful learning-nya John Dewey dan social interaction-nya Vygotsky, dan discovery learningnya Bruner (1996). Menurut teori belajar konstruktivisme, peserta didik mengonstruksi pengetahuan berdasarkan pengala- man yang mereka alami. Oleh karena itu, mereka harus diberi kesempatan untuk be lajar melalui pengalaman dan bereksperimen.

Project based learning dianggap memiliki kelebihan dibanding dengan metode kuliah biasa karena beberapa faktor sebagai berikut. Pertama, PBL dapat memotivasi siswa dengan melibatkan mereka dalam pembelajaran, memberikan kesempatan kepada peserta didik untuk menemukan caranya sendiri dalam memecahkan masalah atau mencari jawab terhadap pertanyaan yang mereka hadapi. Kedua, PBL jugamemberi kesempatan kepada peserta didik untuk belajar secara interdisipliner. Mereka menerapkan dan mengintegrasikan semua pengetahuan dan keterampilan dari berbagai mata pelajaran dalam situasi yang nyata dalam proses menghasikan produk atau pemecahan masalah. Ketiga, PBL membuat belajar bermakna bagi peserta didik kare na mampu menghubungkan kondisi di dalam kelas dengan kehidupan nyata di luar kelas, menghadirkan masalah kehidupan yang nyata dan mengembangkan keterampilan yang laku untuk dipasarkan. Keempat, PBL mampu menyediakan berbagai kesempatan bagi guru untuk menjalin hubungan baik dengan siswa. Guru dapat menjalankan perannya sebagai coach, fasilitator, maupun co-learner.

Terkait dengan pengajaran bahasa, Fried-Booth (2002) mengartikan project work sebagai "student- centered and driven by the need to create an end-product." Proses untuk menghasilkan end-product ini telah memberikan kesempatan kepada siswa untuk mengembangkan rasa percaya diri, kemandirian, bekerja sama dalam berkolaborasi dengan teman-temansekelas. Lee(2005) mengartikan PBL sebagai an instructional approach that contextualizes learning by presenting students with problems to solve and ques- 
tions to answer. Dia menyatakan bahwa PBL membuka kesempatan berharga untuk mengintegrasikan content knowledge dengan belajar bahasa. Beckett dan Slater (2005) menyatakan bahwa PBL adalah cara yang tepat untuk mendorong terjadinya pemerolehan bahasa, pengetahuan dan keterampilan secara simultan. Beberapa penelitian membuktikan bahwa PBL merupakan strategi belajar berdasar tugas dalam belajar bahasa asing yang efektif.

Lesson study dipilih sebagai praktik pelaksanaan pembelajaran karena dengan lesson study dimungkinkan pembinaan profesi pendidik melalui pengkajian pembelajaran secara kolaboratif dan berkelanjutan berdasarkan prinsip-prinsip kolegalitas dansalingmemberi untuk membangun masyarakat belajar. Lesson study merupakan suatu kegiatan praktik pembelajaran dari sejumlah guru dan pakar yang meliputi tiga tahap kegiatan, yaitu: perencanaan (plan), implementasi pembelajaran (do), dan observasi atau refleksi (see) terhadap perencanaan dan implementasi pembelajaran tersebut dalam rangka peningkatan kualitas pembelajaran (Sukirman, 2011).

\section{METODE}

Penelitian ini merupakan penelitian pembelajaran dalam bentuk lesson study. Lesson study ini dilaksanakan di Kelas Pronunciation IB di Jurusan Pendidikan Bahasa Inggris Fakultas Bahasa dan Seni Universitas Negeri Yogyakarta. Mata kuliah ini diselenggarakan di Ruang Cine Club 102, pada semester ganjil tahun 2013/ 2014, yaitu pada tanggal 17 dan 24 N ovember 2013.

Kegiatan ini dilakukan pada Mata kuliah Pronunciation, pada fase production, yaitu setelah semua subtopik selesai dibahas, ketika mahasiswa harus mengaplikasikan semua sub-skill pronunciation yang te lah dipelajari untuk menyiapkan kerja pro- yek secara berkelompok, melakukan pertunjukan di depan publik, memberikan tanggapan dan peer correction, dan menanggapi peer correction dari kelompok lain. Aspek karakteryang dikembangkan meliputi: kerja sama (team work), tanggung jawab, bersikap kritis, terbuka terhadap saran dan pendapat orang lain, adil, dan memahami serta menghargai orang lain.

Lesson study ini dilaksanakan dengan tiga langkah, yaitu perencanaan (plan), implementasi pembelajaran (do), dan observasi serta refleksi (see). Model pembelajaran dirancang menggunakan model projectbased learning dengan langkah-langkah seperti berikut. Pertama, orientasi: dosen menjelaskan tujuan pembelajaran dan model pembelajaran dan segala hal yang harus dilakukan mahasiswa, membagi mahasiswa dalam beberapa kelompok, dan membagikan lembar kerja. Kedua, tahap persiapan: mahasiswa bekerja dalam kelompok, membagi peran, merancang pertunjukan, menyiapkan dan melatih peran-peran. Ketiga, kegiatan di luar kelas: mahasiswa berlatih peran dalam kelompok hingga siap untuk ditampilkan. Keempat, tahap unjuk kerja: dosen menjelaskan model peer assessment dan membagikan lembar assessment kepada mahasiswa. Satu kelompok melakukan unjuk kerjadan kelompok lain mengamati dan mengisi lembarpenilaian. Setelahunjuk kerja selesai, kelompok penilai menyampaikan hasil penilaian dan tanggapannya. Kelima, tahap ini diulang hingga semua kelompok menampilkan pertunjukan yang telah disiapkan.

Data proses pembelajaran direkam dengan video kamera dan diamati oleh semua anggota tim dengan bantuan lembar observasi. Selain Lembar observasi sebagai alat pengumpul data, kegiatan ini juga dilengkapi dengan perangkat pembelajaran yang meliputi: lembar self assessment, lem- 
bar peer assessment, rencana pembelajaran, lembarkerjasiswa, dan naskah drama. Data yangterkumpul dari proses pengamatan dibahas dalam diskusi pada tahap refleksi yang selanjutnya dilaporkan secara deskriptif, sedangkan data dari lembar self assessment dan peer assessment dianalisis secara deskriptif kuantitatif dan dilaporkan dalam bentuk table frekuensi dan persentase untuk memperkuat data kualitatif.

\section{HASIL DAN PEMBAHASAN}

Lesson study ini dilaksanakan melalui tiga tahap, yaitu tahap persiapan, tahap pelaksanaan dan pengamatan, serta tahap refleksi dan evaluasi.

\section{Tahap Persiapan}

Pada tahap ini, anggota tim lesson study mempersiapkan semua perlengkapan yang diperlukan, yaitu menyusun rencana pembelajaran, lembar kerja siswa, mencari naskah drama sebagai materi ajar, menyusun lembar observasi, menyusun lembar evaluasi untuk mahasiswa berupa peer assessment dan self evaluation. Penjelasannya adalah sebagai berikut.

Pertama, menyususn Rencana Pelaksanaan Pembelajaran (RPP). Rencana Pelaksanaan Pembelajaran (RPP) dirancang untuk memberikan arah pembelajaran secara rinci. Kegiatan pembelajaran ini dirancang untuk dilaksanakan dalam dua kali pertemuan dengan tahapan-tahapan secara detail tertuang dalam Rencana Pelaksanaan Pembelajaran.

Kedua, menyusun Lembar Kerja Mahasiswa. Lembar kerja mahasiswa disusun untuk memberikan pedoman bagi mahasiswa apa yang harus dilakukan dalam setiap tahapan pembelajaran. Lembar kerja siswa disusun sebagai pedoman bagi mahasiswa dalam bekerja. Lembar kerja ini disusun berdasarkan langkah-langkah pembelajar- an dalam lesson plan. Lembar kerja ini terdiri atas: lembar kerja untuk pertemuan pertama, lembar kerja untuk berlatih di luar kelas, dan lembar kerja untuk pertemuan kedua.

Ketiga, menyusun lembar observasi. Lembar obsevasi disusun sebagai pedoman bagi para pengamat dalam mengamati jalannya pembelajaran dan untuk menilai apakah tujuan pembelajaran dapat dicapai. Lembar observasi ini dikembangkan menjadi dua macam, yaitu: (1) lembar observasi jalannya pembelajaran; dan (2) lembar observasi perilaku siswa.

Keempat, menyusun lembar peer assessment. Lembar peer assessment dikembangkan untuk mahasiswa sebagai pedoman dalam mengamati dan menilai penampilan teman-temannya dari kelompok lain.

Kelima, menyusun lembar self assessment. Lembar self assessment dikembangkan bagi mahasiswa untuk membantunya dalam melakukan refleksi terhadap pembelajaran yang telah dilakukan.

Keenam, memilih naskah drama. Materi ajar yang digunakan dalam kegiatan ini adalah naskah drama yang dipilih dan diambil dari internet dengan ketentuan: memuat nilai-nilai moral, dimainkan oleh sekitar 7 orang, berdurasi sekitar 15 menit. Dengan mempertimbangkan kriteria tersebut, akhirnya pilihan jatuh pada 3 naskah dramadengan judul: (1) Five $\mathrm{H}$ ouses for $\mathrm{H}$ arriette by A lex Broun dari abroun@bigpond.net.au, 2010; (2) The Grasshoppers and the A nts by Geoge Halitzka dari www.dramabygeorge.com, 2011; dan (3) Lemon Tart by Alex Broun dari abroun@bigpond.net.au, 2007.

\section{Tahap Pelaksanaan dan Refleksi}

Lesson Study ini telah dilaksanakan sesuai dengan rencana, yaitu pada tanggal 17 N ovember dan 24 N ovember 2013, pada 
jam 09.00 sampai dengan 11.00 di Ruang Cine Club 102 FBS UNY. Subjek dalam kegiatan ini adalah Kelas Pronunciation I B yang terdiri dari 20 orang mahasiswa, 1 orang guru model, 1 orang kameramen, dan 4 orang pengamat.

\section{Pelaksanaan Tahap I}

Pelaksanaan tahap pertama dilaksanakan pada tanggal 17 November 2013 jam 09.00 sampai dengan jam 11.00, di Ruang Cine Club 102. Guru model dilakukan oleh Ella Wulandari, MA., kameramen Singgih, pengamat Jamilah, Lusi Nurhayati, Siwi Karmadi Kurniasih, dan Siti Mahripah.

Pembelajaran berjalan sesuai dengan yang direncanakan, yaitu pertama guru membuka pelajaran dengan bertegur sapa, melakukan apersepsi, menjelaskan tujuan pembelajaran, dan teknik pembelajaran yang akan digunakan. Berikutnya guru membagi mahasiswa ke dalam tiga kelompok, membagi lembar kerja siswa, kemudian membuat siswa bekerja dalam kelompok. Siswa bekerja dalam kelompok dengan mengikuti lembar kerja yang telah mereka terima. Guru memonitor, memotivasi dan membantu serta mengarahkan siswa yang masih memerlukan bantuan.

Secara umum, terlihat setiap mahasiswa fokus berlatih di kelompoknya. Me reka sudah membagi peran yang ada dalam naskah drama yang dibagikan guru model. Terlihat bahwa mereka berlatih dengan tekun dan santai. Suasana pembelajaran terasa santai, tetapi juga serius. Se sekali terdengar gelak tawa di salah satu kelompok. Mereka menertawakan beberapakalimat dialog dalam naskah dramayang mereka pelajari. Beberapa kali terlihat proses tanya jawab terjadi di dalam kelompok. Misalnya, mahasiswa yang merasa kurang yakin terhadap cara membaca atau melafalkan kata tertentu bertanya kepada teman lain yang dirasa lebih bisa. Mahasiswa juga secara refleks memberi koreksi terhadap temannya yang melakukan kesalahan daIam melafalkan kata maupun kalimat. Dalam memberikan masukan, kritik atau saran mereka melakukannya dalam suasana akrab, tidak terlihat canggung atau merasa tidak enak. Kendati demikian, pada salah satu kelompok terdapat satu mahasiwa yang terlihat kurang semangat dan cenderung pasif. Dia tidak banyak berbicara ataupun berpartisipasi dalam diskusi dan latihan.

Dosen selalu memantau jalannya latihan dan diskusi. Sesekali dosen juga memberi masukan atau menjawab pertanyaan yang muncul dari mahasiswa. Setelah mahasiwa selesai latihan dan diskusi, dosen kembali menjelaskan kegiatan yang akan dilakukan minggu mendatang. Mahasiswa memperhatikan penjelasan dosen dengan seksama. Mahasiswa sesekali berbisik-bisik di dalam kelompoknya dalam merespons informasi dari dosen. Mahasiswa mengajukan pertanyaan pada dosen terkait apa yang harus dilakukan minggu depan. Dosen memberi penjelasan.

Beberapa menit sebelum waktu berakhir, mahasiswa terlihat gelisah dan beberapa orang melihat jam tangan. Dosen meminta mahasiswa melakukan persiapan di rumah. Dosen juga memberi beberapa strategi yang bisa digunakan untuk performance. Dosen pun mengakhiri perkuliahan pada hari itu.

Setelah proses pembelajaran berakhir, tim lesson study berkumpul dan membahas jalannya pembelajaran. Semua berpendapat bahwa pembelajaran berjalan dengan sangat baik, siswa aktif, bekerja dengan tekun, dan bersikap ceria. Namun demikian, anggota tim menemukan kesulitan dalam membahas satu persatu mahasiswa karena tidak semua pengamat hafal nama-nama 
mahasiswa anggota kelas tersebut sehingga untuk pertemuan berikutnya, setiap mahasiswa akan mengenakan nama yang dipasang di dada dan di punggungnya

Insersi karakter selama pembelajaran dilakukan baik melalui isi perkuliahan maupun aktivitas pembelajaran. Dari segi isi atau konten perkuliahan, drama yang dipilih jelas mengandung muatan nilai moral. Mahasiswa bisa mengambil pelajaran dari setiap karakter yang ada di dalam drama. Karakter yang ada di dalam drama memiliki watak dan sifat yang berbeda. Dari situ mahasiswa bisa belajar untuk memilih dan memilah mana yang baik dan layak ditiru dan mana sifat/ watak yang harus dihindari. Dalam diskusi kelompok, selain berlatih pronunciation mahasiwa juga mendapat peluang untuk menganalisis perilaku setiap karakter yang muncul dalam naskah drama.

Upaya untuk mendidik karakter juga dilakukan melalui aktivitas pembelajaran. Dengan adanya kerja kelompok, mahasiswa mendapat peluang untuk mengimplementasikan beberapa perilaku terpuji. Pertama, bekerja sama. Di dalam kelompok mahasiswa bekersa sama untuk melaksanakan tugas yang diberikan, yaitu menampilkan drama. Mereka mendapat pengalaman bagaimana cara melakukan perencanaan dan latihan. Perencanaan ini meliputi misalnya membagi peran (siapa menjadi siapa/ apa) yang dilakukan secara musyawarah. Mereka juga harus bekerja sama melakukan latihan bersama-sama di ruang kuliah.

Kedua, tanggung jawab. Dengan kerja proyek ini, mahasiswa belajar untuk mengemban tanggungjawab. Untuk dapat menampilkan drama dengan baik, diperlukan kerja sama dan tanggung jawab yang tinggi dari setiap anggota kelompok. Mereka haruskonsekwen. Suka atau tidak suka, ke- tika peran itu sudah diemban, maka mahasiswa harus menjalankannya hingga akhir.

Ketiga, toleransi. Dalam proses pemilihan peran terlihat ada toleransi yang mungkin jadi positif dan juga negatif. Toleransi menjadi positif saat mahasiswa bisa mengusulkan diri untuk menjadi peran tertentu sesuai kesukaan atau kemampuan dia. Mahasiswa yang memiliki skill berbahasa Inggris bagus cenderung mendapat peran utama atau memiliki porsi dialog terbanyak. Sementara mahasiswa yang keterampilannya agak kurang mendapat porsi dialog yang agak sedikit.

Keempat, terbuka terhadap masukan. Ketika latihan dan diskusi, antarteman saling memberi masukan dan juga kritik. Masukan itu disampaikan dengan gaya khas mahasiswa(tidakterlalu formal namun masih bisa diterima oleh teman mereka). Dalam menanggapi masukan mahasiswa terkadang juga mempertahankan argumennya, namun saat menyadari salah mereka pun bisa menerima dengan terbuka.

Kelima, kritis. Mahasiswa cukup sensitif terhadap beberapa kesalahan pronunciation yang dilakukan temannya. Mereka dengan serta merta memberi masukan. Sikap kritis ini juga ditunjukkan saat mereka bertanya kepada dosen. Keenam, sabar. Selama latihan mereka sabar menyimak dialog dan menanti giliran mereka tiba.

\section{Pelaksanaan Tahap II}

Tahapkeduadilaksanakan pada tanggal 24 November 2013 jam 09.00 sampai dengan 11.00 di Ruang Cine Club 102. Kali ini guru model dibawakan oleh Jamilah, operator kamera Singgih, pengamat Lusi Nurhayati, Siwi Karmadi Kurniasih, dan Siti Mahripah.

Pembelajaran berjalan sesuai dengan yang direncanakan, yaitu siswa sudah duduk sesuai dengan kelompok masing-ma- 
sing. Guru membuka pelajaran dengan memberi salam, dan menanyakan persiapan mahasiswa, apakah mereka sudah siap dengan pertunjukan. Mahasiswa menjawab dengan cara yang beragam. Salah seorang mahasiswa menjawab tidak siap. Dosen bertanya: "Why?" Mahasiswa menjawab: "mental". Mahasiswa lain tertawa mendengar jawabannya.

Dosen menerangkan kembali aturan main dalam drama performance. Dosen juga menerangkan bahwa penampilan mereka dinilai oleh sesama teman dan mereka juga harus melakukan self assessment. Dosen menjelaskan bahwa mereka akan diberikan lembar penilaian dan harus diisi sesuai aturan penilaian selama peer assessment. Setelah mahasiswa mengerti prosedur penilaian dan rencana kegiatan hari itu, dosen membagikan lembar kerja yang harus diisi oleh mahasiswa, yaitu peer assessment dan self assessment.

Selanjutnya, tiba saatnya mahasiswa tampil, dosen menawarkan kelompok yang akan maju terlebih dulu. Satu kelompok meminta maju nonor urut 2, kelompok lain meminta tidak maju lebih dulu karena anggotanya belum lengkap. Akhirnya, salah satu kelompok diminta maju pertama (keIompok Olia). Mereka bersedia karena tidak punya alasan lain untuk menolak kendatipun mengaku merasa belum siap.

Kelompok satu melakukan persiapan, beberapa mahasiswa nampak membawa notes/ catatan kecil. Persiapan ini nampaknya terlalu lama. Mereka seperti bingung apa yang harus dilakukan lebih dulu. Salah satu mahasiswa putra di grup ini mengatakan, "A ku lali kabeh." Temannya tersenyum dan tertawa kecil. Mereka kemudian terlihat mendiskusikan sesuatu. Akhirnya, pada pukul 9.25 semua anggota maju, Andiyani membuka performance dengan menyapa teman-teman. Lalu mengatakan ju- dul penampilan mereka. Andyani mengakhiri pembukaannya dengan mengatakan: "Please enjoy."

Budi dan Andiyani memulai performance, masih ada kesalahan pronunciation oleh budi (misalnya dalam pelafalan kata talking). Meski begitu, dalam hal intonasi, kekuatan suara, ekspresi juga turn taking selama dialog antarkeduanya berjalan cukup baik. Sayang Budi lupa dialog jadi harus melihat catatan kecilnya berkali-kali sehingga ada pause cukup lama. Olia suaranya kurang keras dan terdengar seperti bergumam. Dia juga sering membelakangi pemirsa. Sarah melakukan kesalahan dalam melafalkan kata (heart, hurt).

Setelah kelompok satu tampil, tiba waktu untuk feedback dan kritik. Dosen meminta mahasiswa untuk memberikan kritik dan saran. Ketika ditawarkan siapa yang lebih dulu memberi masukan, mahasiwa agak ragu, baru setelah ditunjuk per kelompok kritikan dari mahasiwa muncul. Rata-ratamahasiwa mengangkat kekurangan yang mereka temukan tanpa menyebutkan kelebihannya (bloking, jeda, kurang jelas, eye contact), kecuali salah satu mahasiwa yang bisa memberi masukan secara imbang, yaitu membahas sisi positif dan negatifnya. Kelompok yang tampil juga diberi kesempatan untuk melakukan refleksi diri. Mereka mengaku merasa grogi sehingga lupa dialog. Lebih jauh mereka mengatakan kurang latihan. Mereka mengatakan telah berlatih selama 5 hari, tetapi tidak dirinci berapa jam.

Selanjutnya, dosen mempersilakan kelompok berikutnya untuk maju. Kelompok 2 mengawali penampilan dengan berbaris dan menyapa pemirsa. Lalu drama pun dimulai. Kelompok ini lebih baik dari segi suara dan ekspresi. Namun intonasi dalam"pertengkaran" kurang natural. Pada saat sesi kritik dan saran, penampilan 
kelompk 2 dinilai lebih baik dibanding kelompok 1 oleh sebagian besar pengkritisi.

Grup 3 mengawali penampilan dengan perkenalan. Berbeda dengan penampilan 2 atau kelompok sebelumnya, kelompok ini menerangkan "siapa menjadi apa/ siapa" dalam drama ini sehingga pembukaan kelompok ini relatif lebih lama. Sekilas terlihat kelompok ini lebih percaya diri dibanding kelompok lain walau sebenarnya mereka kehilangan salah satu pemeran utama dan itu menyebabkan performance agak terganggu. Namun salah satu peserta, Ulfatun, jarang bicara dan kurang ekspresif. Penampilan mereka dikomentari baik oleh sesama mahasiswa. Salah satu mahasiswa mengatakan sebagian besar mereka terlalu terlihat mencontek, membaca terlalu banyak dan hanya melihat lawan bicara.

Setelah PBM berakhir, tim lesson study berkumpul untuk membahas jalannya pembelajaran dan hasil pembelajaran. Pembelajaran sudah berjalan sesuai dengan yang diharapkan, lancar, dan cukup memuaskan.

Dalam kerangka penanaman karater yang baik, dapat dikatakan bahwa beberapakarakter baik, seperti: kerjasama, tanggung jawab, percaya diri, kritis, menghargai karya orang lain, menyampaikan pendapatdengan santun, terbuka terhadap ma sukan, dan bersikap adil dalam memberi penilaian sudah muncul dengan baik. Pertama, keberanian, yakni walaupun mereka tidak mempunyai pengalaman bermain drama, mereka berani mencoba, berani mengkritik teman, dan berani menerima kritikan orang lain. Kedua, tanggung jawab, yakni untuk dapat menampilkan drama mereka, juga melakukan latihan yang intensif di luar kelas dengan kesadaran sendiri. Ini adalah salah satu wujud kerja keras dan tanggung jawab mereka terhadap tugas yang diemban. Memang ada salah satu mahasisa yang tidak datang tanpa kabar dan membuat suasana penampilan drama kelompoknya agak terhambat dan kurang maksimal, tetapi ini hanya salah satu kasus saja. Ketiga, bersikap adil, yakni mahasiswa bersikap adil dalammemberi penilaian. Adil dalam arti penampilan bagus dikatakan bagus, dan yang kurang dikatakan kurang.

Keempat, kerja sama, yakni dalam menampilkan drama dibutuhkan kerjasama yang tinggi dan juga pengertian antarsesama anggota. Mahasiswa telah menunjukan bahwamereka bekerja sama untuk mengerjakan tugas ini, mulai dari melakukan perencanaan bersama, latihan bersama, dan tampil bersama. Tanpa latihan di luar kelas tidak akan mungkin mereka bisa tampil dengan cukup baik. Kelima, menghargai orang lain, karena pada saat yang sama mahasiwa juga menunjukkan kemampuannya dalam mengapresiasi dan menghargai karya orang lain, misalnya dengan jalan memberi pujian dan tepuk tangan. Keenam, toleransi, berupa kelompok pertama me nunjukan sikap toleransi yang tinggi. Me reka merelakan diri untuk maju terlebih dahulu karena kelompok lain belum memungkinkan untuk maju, terutama kelompok 3 karena anggotanya belum lengkap. Ketujuh, percaya diri, mahasiswa juga cukup percaya diri untuk tampil di depan teman-teman, 3 orang observer dan satu cameraman. Meski seluruh proses direkam tidak tampak mereka tidak percaya diri karena ini. Kedelapan, terbuka terhadap kritik dan saran teman. Sikap ini muncul ketika mereka mendapat kritikan. Sebagian besar mahasiswa bisa menerima kritikan dengan besar hati dan terbuka. Mereka mengakui masih memiliki kekurangan dan kelemahan dalam penampilan.

Selain data kualitatif dari hasil pengamatan, nilai moral dan karakter yang dipelajari mahasiswa melalui kegiatan pembelajaran ini juga diperkuat dengan data 
kuantitatif yang dikumpulkan melalui self assessment yang diisi olah mahasiswa. Dari self assessment yang mereka isi, diperoleh data seperti disajikan pada Tabel 1.

Berdasarkan Tabel 1 tampak bahwa mahasiswamerasa telah belajar banyak me Ialui project-based learning. Dari data ini dapat dilihat bahwa mereka paling banyak telah belajar untuk memahami orang lain dan tenggang rasa (toleransi), menghargai orang lain, bertanggung jawab, bekerja sama dalam tim dan bersikap adil dan terbuka. Sikap kritis mendapat respon paling rendah, karena hanya 5 orang mahasiswa (25\%) yang mengatakan telah banyak belajar sikap ini dalam proses pembelajaran, diikuti dengan sikap terbuka terhadap saran dan masukan orang lain. Dua sikap inilah yang masih belum dapat dikembangkan dengan maksimal melalui kegiatan ini menurut pengakuan mahasiswa.

Hal kedua yang diperoleh dari self assessment adalah tentang penilaian mahasiswa terhadap kinerja mereka sendiri.
Dari sembilan pertanyaan yang diajukan diperoleh data yang disajikan pada Tabel 2

Berdasarkan Tabel 2, diperoleh informasi bahwa $100 \%$ mahasiswa menyatakan senang belajar dengan cara ini, 95\% menyatakan telah bersikap terbuka, 84\% menyatakan bangga terhadap penampilan kelompoknya, $84 \%$ telah melihat kelemahan kelompok lain, namun hanya $74 \%$ yang menyatakan melihat kelemahan kelompoknya sendiri, 79\% menyatakan banyak dibantu, namun hanya $63 \%$ yang merasa banyak membantu. Indikator yang mendapat respon rendah adalah indikator 1 dan 4 . Hanya $53 \%$ mahasiswa yang merasa telah bekerja semaksimal mungkin, sedang yang lainnya menyatakan belum, dan hanya 42\% mahasiswa yang menyatakan yakin dengan penampilannya sendiri. Dari data ini dapat diketahui bahwa mereka merasa belum bekerja semaksimal mungkin untuk pertunjukan tersebut dan juga belum cukup percaya diri dengan penampilan sendiri.

Tabel 1. Nilai-nilai M oral yang D ipelajari M ahasiswa dalam PBM

\begin{tabular}{llccccc}
\hline No & Yang Dipelajari & Sangat Banyak & Banyak & Cukup & Sedikit & Skor Total \\
\hline 1. & Pronunciation & 2 & 10 & 3 & 4 & 48 \\
2. & Kerjasama dlm tim & 2 & 10 & 5 & 2 & 50 \\
3. & Tanggung jawab & 2 & 12 & 5 & 0 & 54 \\
4. & Memahami orang lain & 1 & 16 & 2 & 0 & 56 \\
5. & Tenggang rasa & 2 & 14 & 3 & 0 & 56 \\
6. & Menghargai karya orang lain & 4 & 12 & 3 & 0 & 56 \\
7. & Menilai dengan adil & 2 & 11 & 6 & 0 & 53 \\
8. & Bersikap kritis & 0 & 6 & 10 & 3 & 41 \\
9. & Terbuka terhadap saran dan & 3 & 10 & 5 & 1 & 43 \\
& masukan orang lain & & & & & \\
\hline
\end{tabular}

\section{Tabel 2 Kinerja Mahasiswa}

\begin{tabular}{llcc}
\hline No. & Indikator Kinerja & Ya & Tidak \\
\hline 1. & Telah bekerja sebaik mungkin & $10(53 \%)$ & $9(47 \%)$ \\
2. & Banyak membantu teman & $12(63 \%)$ & $7(37 \%)$ \\
3. & Banyak dibantu teman & $15(79 \%)$ & $4(21 \%)$ \\
4. & Yakin akan penampilan sendiri & $8(42 \%)$ & $11(58 \%)$ \\
5. & Bangga terhadap penampilan kelompoknya & $16(84 \%)$ & $3(16 \%)$ \\
6. & Menemukan banyak kelemahan kelompok sendiri & $14(74 \%)$ & $5(26 \%)$ \\
7. & Menemukan banyak kelemahan pada kelompok lain & $16(84 \%)$ & $3(16 \%)$ \\
8. & Menerima kritik dan saran orang lain & $18(95 \%)$ & $1(5 \%)$ \\
9. & Senang belajar dengan cara ini & $19(100 \%)$ & 0 \\
\hline
\end{tabular}




\section{PENUTUP}

Project-based learning adalah model pembelajaran yangterpadu, menyenangkan, dan tepat untuk menanamkan sikap dan nilai moral kepada peserta didik. Dengan project-based learning, siswa tidak hanya mempelajari konsep-konsep dalammata pelajaran yang dipelajari, tetapi lebih pada penerapan konsep-konsep dalam dunia nyata untuk menghasilkan karya tertentu. Siswa tidak hanya mengembangkan aspek kognitif saja melainkan juga keterampilan dan nilai-nilai moral serta sikap terpuji lainnya. Selain itu, project based-learning juga tepat digunakan dalam pengajaran bahasa asing, tanpa kecuali pronunciation .

Pada proses menghasilkan karya inilah siswa berinteraksi dengan teman-teman sekelompok maupun dari kelompok lain. Prosesinteraksi inilahyang diperlukan oleh siswa dalam belajar bahasa asing agar dapat menggunakan bahasa target dalam situasi yang sesungguhnya. Dalam proses interaksi ini pula siswa memiliki kesempatan untuk memahami orang lain, belajar menyampaikan pendapat dan saran dengan santun, menerima pendapat dan saran dari orang lain. Untuk dapat menghasilkan karya tertentu, misalnya karya pertunjukan, siswa dituntut untuk bekerjasama dalam tim, bertanggung jawab, dan memiliki rasa percaya diri yang tinggi untuk mampu tampil di depan publik.

\section{UCAPAN TERIMA KASIH}

Penulis mengucapkan terima kasih yang setulus-tulusnya kepada semua pihak yang telah membatu kelancaran penelitian dan penulisan ini. Ucapan terima kasih terutama tujukan kepada penyunting Jurnal Pendidikan Karakter yang bersedia melakukan review naskah ini hingga dimuat di terbitan pada edisi kali ini.

\section{DAFTAR PUSTAKA}

Becket, G.H. and Slater, T. 2005. "The Project Framework: A Tool for Language Content and Skills Integration". ELT Journal, 59 (2), 108-116.

Bruner , J. 1996. The Culture of Education. Cambridge, MA: Harvard University Press.

Farrels, T.S.C. 2004. Reflecting on Classroom Communication in Asia. Singapore: Longman.

Fried-Booth, D. L. 2002. Introduction, Resource Book for Teachers: Project Work. Oxford: Oxford University Press.

Kelly, G. 2000. How to Teach Pronunciation. London: Longman.

Lee, I. 2005. "The Implementation of Project Based Learning: A Study of Two Hong Kong Secondary English Classrooms". Journal of A sia TEFL. 2 (1), 21-54.

Paulston, Christina Bratt \& Bruder, Mary Newton. 1976. Teaching English as a Second Language: Techniques and Procedures. London: Wadsworth Pub Co.

Sukirman. 2011. “Implementasi Pendidikan Karakter dalam Perkuliahan melalui Lesson Study (Suatu Alternatif). Paper dalam Pelatihan Pengintegrasi Karakter dalam Perkuliahan melalui Lesson Study. Yogyakarta: UNY.

Universitas Negeri Yogyakarta. 2006. Kurikulum Program Studi Pendidikan Bahasa Inggris. Yogyakarta: UNY Press.

Wang Ge. 2006. “Language Teacher Research in Asia: Does Project-Based Learning Work in Asia (China)?" Dalam Thomas S.C. Farrell (ed). TESO L. Canberra: Inc. Canberra.

Zuchdi, Darmiyati, dkk. 2010. Pendidikan Karakter dengan Pendekatan Komprehensif Terintegrasi dalam Perkuliahan dan Pengembangan Kultur U niversitas. Yogyakarta: UNY Press. 